Article

\title{
Effects of Different Storage Conditions on the Browning Degree, PPO Activity, and Content of Chemical Components in Fresh Lilium Bulbs (Lilium brownii F.E.Brown var. viridulum Baker.)
}

\author{
Kanghong Zhao ${ }^{1,2}$, Zhengpeng Xiao ${ }^{1,2}$, Jianguo Zeng ${ }^{1,2}$ and Hongqi Xie ${ }^{1,2, *}$ \\ 1 National and Reginal Joint Engineering Research Centre for Veterinary Traditional Chinese Medicine \\ Resources and Traditional Chinese Veterinary Medicine Innovation, Hunan Agricultural University, \\ Changsha 410128, China; kanghongz@163.com (K.Z.); x2300379299@163.com (Z.X.); \\ zengjianguo@hunau.edu.cn (J.Z.) \\ 2 National Technology Center (Hunan) for Traditional Chinese Medicine Production, \\ Hunan Agricultural University, Changsha 410128, China \\ * Correspondence: xiehongqi@hunau.edu.cn; Tel.: +86-158-7400-1185
}

check for updates

Citation: Zhao, K.; Xiao, Z.; Zeng, J.; Xie, H. Effects of Different Storage Conditions on the Browning Degree, PPO Activity, and Content of Chemical Components in Fresh Lilium Bulbs (Lilium brownii

F.E.Brown var. viridulum Baker.). Agriculture 2021, 11, 184. https:// doi.org/10.3390/agriculture11020184

Received: 21 January 2021

Accepted: 20 February 2021

Published: 23 February 2021

Publisher's Note: MDPI stays neutral with regard to jurisdictional claims in published maps and institutional affiliations.

Copyright: (c) 2021 by the authors. Licensee MDPI, Basel, Switzerland. This article is an open access article distributed under the terms and conditions of the Creative Commons Attribution (CC BY) license (https:// creativecommons.org/licenses/by/ $4.0 /)$.

\begin{abstract}
Although Lilium brownii (L. brownii) bulbs are popular fresh vegetables, a series of quality problems still remain after harvest. In this study, fresh L. brownii bulbs were placed in the dark at 25 , 4 , and $-20^{\circ} \mathrm{C}$ and under light at $25^{\circ} \mathrm{C}$ from 0 to 30 days; the chemical compositions were analyzed by ultraviolet spectrophotometry (UV) and high-performance liquid chromatography quadrupole time-of-flight mass spectrometry (HPLC-Q-TOF-MS). During the 30-day storage period, the browning degree increased over the storage time and with increasing temperature, but the contents of proteins and free amino acids decreased and were aggravated by light. The total polyphenol content increased until the 6 th day at $25^{\circ} \mathrm{C}$ (dark or light), but it did not significantly accumulate at -20 or $4{ }^{\circ} \mathrm{C}$. The reducing sugar content showed a dynamic balance, but the total polysaccharide content decreased constantly in the four storage conditions. The polyphenol oxidase (PPO) activity increased with storage time and increasing temperature, while it was inhibited by light. The increase rates of malondialdehyde (MDA) content at $-20^{\circ} \mathrm{C}$ and light $\left(25^{\circ} \mathrm{C}\right)$ were higher than those at 4 and $25^{\circ} \mathrm{C}$. In addition, 12 secondary metabolites were identified, most of which accumulated during the storage period, for example, 1-O-feruloyl-3-O- $\beta$ - $D$-glucopyranosylglycerol; 1,3-O-di- $p$-coumaroylglycerol; 1-O-feruloyl-3-O-p-coumaroylglycerol; and 1,2-O-diferuloylglycerol. The variations in nutrient levels had a low correlation with browning, but the variations in MDA, PPO, and secondary metabolite (phenolic acids) levels had a high correlation with browning. In conclusion, fresh L. brownii bulbs should be stored at a low temperature $\left(4^{\circ} \mathrm{C}\right)$ and in dark condition, and browning bulbs are excellent materials for secondary metabolite utilization.
\end{abstract}

Keywords: Lilium bulbs; postharvest; metabolites; principal component analysis

\section{Introduction}

The genus Lilium has over 110 species in the world, of which 55 species are found in China [1]. In addition, Lilium is an important traditional Chinese medicine and edible food, and it is widely used as a horticultural ornamental plant. Three species of Lilium (Lilium lancifolium Thunb., Lilium brownii F.E.Brown var. viridulum Baker., and Lilium pumilum DC.) have been recorded by Chinese Pharmacopoeia [2] and listed as a medicine food homology by China's ministry of Health [3]. Lilium brownii F.E.Brown var. viridulum Baker. bulbs (L. brownii), with a long medicinal history and active ingredients (such as polyphenols, saponins, and polysaccharides) [4,5], has been shown to have anti-inflammatory, anti-tussive, hypoglycemic, antioxidant, immune-modulatory, and anti-tumor effects [6,7]. Apart from their bioactivities, L. brownii is mainly enjoyed by consumers for its edible properties. 
Polysaccharide, protein, amino acids, phospholipid, and starch (primary metabolites) are probably the most important parameters [8].

Fresh L. brownii bulbs often display a series of quality issues, such as browning, nutrient loss, or secondary metabolite transformation during the storage period, all of which impact the edibleness, medicinal value, and commercial value [9]. The browning can be divided into enzymatic browning and non-enzymatic browning. Enzymatic browning is caused by polyphenol oxidase (PPO) [10]. In the presence of oxygen, phenolic compounds are oxidized to quinones, and accumulation of quinones on the surface of tissues causes a brown-to-black stripe to form after further non-enzymatic oxidation [11]. It is noteworthy that phenolic compounds from L. brownii bulbs are not only substrates of enzymatic browning but secondary metabolites with anti-inflammatory and antioxidant activities. The aim of this study is to explore whether it accumulates under stress physiology [12], as in stilbenes (as a plant antitoxin and bioactive component [13]) in grapes during storage, which can provide an important basis for its preparation and utilization. It is of great significance to study the substrate for enzymatic browning and pharmacological activities of L. brownii bulbs. In addition, due to the regional structure of cells, enzymes and substrates are in different spaces, and the premise of their contact is that the cell regionalization is broken. Therefore, malondialdehyde (MDA), as an indicator of membrane lipid peroxidation, is related to the degree of cell membrane damage and is also an important indicator for the study of plant physiology and biochemistry after harvest [14]. Non-enzymatic browning is mainly caused by the Maillard reaction, also known as the carbonyl ammonia reaction, which is widely used in the processing of tea, cocoa, etc., but its detailed mechanism is still unclear [15]. At present, the Maillard reaction model proposed by Hodge is more recognized, and its initial stage involves dehydration condensation of amino-group-containing compounds and carbonyl-containing compounds [16]. The amino-group-containing compounds mainly refer to free amino acids, while the carbonyl-containing compounds mainly point to sugars, especially reducing sugars [17]. While at present there is more extensive research on the browning mechanism than in previous decades, the compounds that are involved in the browning of fresh L. brownii bulbs are affected by a series of life activities and physicochemical factors during the storage period, and their relationship with browning still needs further characterization.

In general, a plant's exuberant metabolism makes it easy for a series of physiological changes to occur in the course of storage, transportation, and sales [18]. Moreover, improper preservation can also cause deterioration of quality and greatly reduce the nutritional quality of L. brownii [19]. Despite the rapid development of the logistics industry, fresh L. brownii bulbs still need multiple procedures, from excavation to the finished product. According to a field survey (Lanzhou, Gansu, China; Longhui and Longshan, Hunan, China), it takes at least 3-7 days of logistics for it to leave the production area. The whole process is relatively long, and the quality of L. brownii bulbs is often clearly reduced. In the process of storage and transportation, L. brownii bulbs often face unsuitable storage temperatures, and this accelerates the deterioration rate of fresh bulbs [20]. In the process of offline sales, in order to provide L. brownii bulbs with an excellent outward appearance, fluorescent lamps are usually applied. However, this results in apparent factor changes, of which, the main manifestation is redness [21,22]. At present, even with mature preservation techniques, addressing fresh $L$. brownii quality problems during storage and transportation remains a challenge; therefore, it is necessary to analyze the details of chemical composition variation during fresh $L$. brownii storage.

In this study, the aims are to (i) study the primary and secondary metabolite content variation in fresh L. brownii bulbs during storage from the perspective of the browning mechanism, thereby providing assistance to the study of preservation technology regarding plant-derived food; (ii) explore the pathway to improve the yield of secondary metabolites in L. brownii bulbs. 


\section{Materials and Methods}

\subsection{Chemicals and Instruments}

The formic acid, acetonitrile, and methanol used for high-performance liquid chromatography (HPLC) analysis were chromatographic grade and purchased from Merck KGaA (Shanghai, China). The ethanol, anthrone, sulphuric acid, glucose, DNS (3,5dinitrosalicylic acid), phenol, hydrochloric acid, sodium carbonate, sodium dihydrogen phosphate, disodium hydrogen phosphate, catechol, guaiacol, and hydrogen peroxide solution were all analytical purity (AR) and obtained from Sinopharm Chemical Reagent Co., Ltd. (Shanghai, China). The bovine serum albumin (BSA), Coomassie Bright Blue G-250, Foline-phenol, and gallic acid were purchased from Yuan-ye Bio-Technology Co., Ltd. (Shanghai, China).

The ultraviolet spectrophotometer (UV-1800) was purchased from Shimadzu Co., Ltd. (Kyoto, Japan). The analytical balance (XS 250) was obtained from METTLER TOLEDO (Columbus, OH, USA). The high-speed centrifuge (2-16R) was purchased from HENGNUO Instrument Equipment Co., Ltd. (Changsha, Hunan, China).

\subsection{Plant Material}

Fresh bulbs of L. brownii brownii F.E.Brown var. viridulum Baker. were provided by Hunan Lvyuan Agricultural Development co., Ltd. (Shaoyang, Hunan, China) in July, 2019, and identified by Jianguo Zeng, from Hunan Agricultural University. The experiment was conducted in National Center (Hunan) for Traditional Chinese Medicine Production Technology $\left(E: 113.0853^{\circ} ; \mathrm{N}: 28.1836^{\circ}\right)$, Hunan Agricultural University, Changsha, China. The bulbs were peeled and washed with cold water, dried surface moisture by hair drier with cold air blast model, and then stored under 4 conditions: Group 1 (G1) was placed in a $-20{ }^{\circ} \mathrm{C}$ refrigerator. Group 2 (G2) was placed in a $4{ }^{\circ} \mathrm{C}$ refrigerator. Group 3 (G3) was placed in a dark room (temperature $=25 \pm 2{ }^{\circ} \mathrm{C}$ ). Group 4 (G4) was placed under the light $\left(\mathrm{d}=60 \mathrm{~cm}\right.$, temperature $\left.=25 \pm 2{ }^{\circ} \mathrm{C}\right)$.

The samples were taken randomly once every 6 days during storage process.

\subsection{Measurement of Browning Degree}

The browning degree was determined as described by Jeong-Seok Cho and KwangDeog Moon [23] with a slight modification. In short, three samples $(5.0 \pm 0.01 \mathrm{~g})$ were randomly sampled, $10 \mathrm{~mL} 0.2 \% \mathrm{~V}_{\mathrm{C}}$ solution was added and homogenized in ice bath, an additional $15 \mathrm{~mL}$ was used to wash the residue to a $50-\mathrm{mL}$ centrifuge tube. The homogenate was centrifuged at $8000 \mathrm{rpm}$ for $20 \mathrm{~min}$ at $4{ }^{\circ} \mathrm{C}$. After it, the supernatant was centrifuged again under the same conditions. The absorbance of the resulting solution was measured at $420 \mathrm{~nm}$, and the $0.2 \% \mathrm{~V}_{\mathrm{C}}$ solution used as blank group.

\subsection{Measurement of Total Carbohydrates}

The extracted and determined methods of total carbohydrates were referred to by $\mathrm{Ji}$ Zhang, et al. [24] with a slight modification. In short, three samples (5.0 $\pm 0.01 \mathrm{~g})$ were randomly sampled, $150 \mathrm{~mL}$ distilled water was added and homogenized, extracted by heating in water bath at $65^{\circ} \mathrm{C}$ for $6 \mathrm{~h}$. Then, the extraction solution was centrifuged at $8000 \mathrm{rpm}$ for $30 \mathrm{~min}$ at $4{ }^{\circ} \mathrm{C}$ after it cooled to room temperature, $1.0 \mathrm{~mL}$ supernatant was diluted 50 times and taken as the sample to be tested.

The content was quantified using the anthracenone-sulfuric method at $625 \mathrm{~nm}$ and determined comparing the absorbance of sample with respect to a standard curve of glucose.

\subsection{Measurement of Total Reducing Sugars}

The extracted and determined methods of reducing sugars were referred to by Jun Chen, et al. [25] with a slight modification. In short, three samples $(5.0 \pm 0.01 \mathrm{~g})$ were randomly sampled, $100 \mathrm{~mL}$ water-ethanol $(v / v=20 / 80)$ was added and homogenized, using reflux extraction at $85^{\circ} \mathrm{C}$ for $1 \mathrm{~h}$. Then, the extraction solution was centrifuged at 
$8000 \mathrm{rpm}$ for $30 \mathrm{~min}$ at $4{ }^{\circ} \mathrm{C}$ after it cooled to room temperature, $1.0 \mathrm{~mL}$ supernatant was taken as the sample to be tested.

The content was quantified using the 3,5-dinitrosalicylic acid (DNS) method at $540 \mathrm{~nm}$ : $1.0 \mathrm{~mL}$ sample was mixed with $1.5 \mathrm{~mL}$ DNS reagent (2.5 g 3,5-dinitrosalicylic acid, $0.5 \mathrm{~g}$ phenol, $0.075 \mathrm{~g}$ sodium nitrite, $2.5 \mathrm{~g} \mathrm{NaOH}$, and $50 \mathrm{~g} \mathrm{KNaC}{ }_{4} \mathrm{H}_{4} \mathrm{O}_{6} \cdot 4 \mathrm{H}_{2} \mathrm{O}$ were dissolved into a spot of distilled water one by one and then to a constant volume to $50 \mathrm{~mL}$ ), and determined by comparing the absorbance of sample with respect to a standard curve of glucose.

\subsection{Measurement the Content of Water-Soluble Protein}

The extracted and determined methods of water-soluble protein were referred to by Xiaoqiang Chen, et al. [26] with a slight modification and simplification: three samples ( $5.0 \pm 0.01 \mathrm{~g})$ were randomly sampled, $100 \mathrm{~mL}$ distilled water was added and homogenized, extracted by heating in water bath at $65^{\circ} \mathrm{C}$ for $4 \mathrm{~h}$. Then, the extraction solution was centrifuged at $8000 \mathrm{rpm}$ for $30 \mathrm{~min}$ at $4{ }^{\circ} \mathrm{C}$ after it cooled to room temperature, $1.0 \mathrm{~mL}$ supernatant was diluted 5 times and taken as the sample to be tested.

The content of water-soluble protein was quantified using the Coomassie Brilliant Blue method at $595 \mathrm{~nm}$ and determined by comparing the absorbance of sample with respect to a standard curve of bovine serum albumin (BSA).

\subsection{Measurement of Free Amino Acids Content}

The extracted and content determined methods of free amino acids were referred to GB/T 8314-2013 (Tea-determination of free amino acids content) [27] with a slight modification and simplification: three samples $(2.0 \pm 0.01 \mathrm{~g})$ were randomly sampled, $100 \mathrm{~mL}$ distilled water was added and homogenized, extracted by heating in water bath at $100{ }^{\circ} \mathrm{C}$ for $1 \mathrm{~h}$. Then, the extraction solution was centrifuged at 12,000 rpm for $30 \mathrm{~min}$ at $4{ }^{\circ} \mathrm{C}$ after it cooled to room temperature, $0.5 \mathrm{~mL}$ supernatant was taken as the sample to be tested.

The preparation of ninhydrin solution: $2.0 \mathrm{~g}$ ninhydrin monohydrate and $80 \mathrm{mg}$ stannous chloride were added into $50 \mathrm{~mL}$ distilled water, reaction in dark for $24 \mathrm{~h}$ after ultrasonic assisted dissolution. The supernatant was diluted to $100 \mathrm{~mL}$ after filtration. Determination method: $0.2,0.4,0.6,0.8$ and $1.0 \mathrm{mg} / \mathrm{mL}$ arginine standard solution were prepared with distilled water, and transfered $0.5 \mathrm{~mL}$ into the test tube respectively. Then $0.2 \mathrm{~mL}$ phosphate buffer solution $(\mathrm{pH}=8.0)$ and $0.2 \mathrm{~mL}$ ninhydrin solution were added. Finally, it was soaked in boiling water for $15 \mathrm{~min}$, and diluted to $10 \mathrm{~mL}$ with distilled water after it cooled to room temperature with ice water. The free acids content was quantified at $570 \mathrm{~nm}$ and determined comparing the absorbance of sample with respect a standard curve of arginine.

\subsection{Measurement of Total Phenolics Content}

The extracted and determined methods of total phenolics were referred to by Lei Jin, et al. [28] with a slight modification: three samples $(5.0 \pm 0.01 \mathrm{~g})$ were randomly sampled, $100 \mathrm{~mL}$ water-ethanol $(v / v=20 / 80)$ was added and homogenized, using ultrasound extraction at $40^{\circ} \mathrm{C}$ for $30 \mathrm{~min}$. Then, the extraction solution was centrifuged at $8000 \mathrm{rpm}$ for $30 \mathrm{~min}$ at $4{ }^{\circ} \mathrm{C}$ after it cooled to room temperature, $1.0 \mathrm{~mL}$ supernatant was taken as the sample to be tested.

The content of total phenolics was quantified by the Folin-Ciocalteu method at $765 \mathrm{~nm}$ : $1.0 \mathrm{~mL}$ sample was mixed with $0.5 \mathrm{~mL}$ Folin solution and $1.0 \mathrm{~mL} 15 \% \mathrm{Na}_{2} \mathrm{CO}_{3}$ was added after $5 \mathrm{~min}$, and then constant volume with distilled water to $10 \mathrm{~mL}$. Then, determined comparing the absorbance of sample with respect to a standard curve of gallic acid.

\subsection{Measurement of Polyphenol Oxidase Activity}

The extraction and measurement of PPO were carried out using a modification of the method of M. Siddiq and K.D. Dolan [29]. Briefly, $2.0 \mathrm{~g}$ L. brownii bulbs were blended in 
$10 \mathrm{~mL}$ of $\mathrm{pH} 6.0$ phosphate buffer and homogenized in an ice bath. Then, centrifuged at $8000 \mathrm{rpm}, 4^{\circ} \mathrm{C}$ for $20 \mathrm{~min}$ in a refrigerated centrifuge.

The PPO activity measurement: the reaction mixture consisted of $1.0 \mathrm{~mL}$ of $0.1 \mathrm{M}$ catechol in $3.9 \mathrm{~mL}$ phosphate buffer $(\mathrm{pH}=6.0)$ and $0.2 \mathrm{~mL}$ of PPO extract, determination after heat preservation at $25^{\circ} \mathrm{C}$ for $5 \mathrm{~min}$. The change in absorbance at $420 \mathrm{~nm}$ was observed for $3 \mathrm{~min}$ at $25^{\circ} \mathrm{C}$, using an ultraviolet spectrophotometer. The reaction velocity (V) was calculated from the linear part of the plot of absorbance (A) against time (t). The unit of $\mathrm{PPO}$ activity was defined as the change in the absorbance of $0.001 / \mathrm{min}(\triangle \mathrm{A} 420 \mathrm{~nm} / \mathrm{min})$ due to the oxidation of substrate.

\subsection{Measurement of MDA Content}

The extraction and measurement of MDA were carried out using a modification of the method of Janero, D. R. [30]. The preparation of test solution: $100( \pm 5) \mathrm{mg}$ samples were put into a $2 \mathrm{~mL}$ centrifuge tube, $1.0 \mathrm{~mL} \mathrm{10 \%} \mathrm{TCA} \mathrm{was} \mathrm{added,} \mathrm{and} \mathrm{homogenized} \mathrm{with}$ tissue grinder. The homogenate was centrifuged at $4{ }^{\circ} \mathrm{C}$ and $12,000 \mathrm{rpm}$ for $20 \mathrm{~min}$, and the supernatant was the test solution.

The determination method: $200 \mu \mathrm{L} 10 \% \mathrm{TCA}$, test solution and TBA working solution ( $0.68 \%$ TBA solution, prepared with $10 \%$ TCA) were added into a $2 \mathrm{~mL}$ centrifuge tube. After 15 min of boiling water bath, it was cooled and centrifuged at $4{ }^{\circ} \mathrm{C}$ and $12,000 \mathrm{rpm}$ for $10 \mathrm{~min}$. The absorbance values were measured at $\lambda=450,532$, and $600 \mathrm{~nm}$. The results were calculated by empirical formula: MDA content $(\mu \mathrm{M})=6.45 \times\left(\mathrm{A}_{532 \mathrm{~nm}}-\mathrm{A}_{600 \mathrm{~nm}}\right)$ $-0.56 \times \mathrm{A}_{450 \mathrm{~nm}} ; \mathrm{MDA}$ content $(\mu \mathrm{mol} / \mathrm{mg})=$ MDA content $(\mu \mathrm{M}) \times$ extraction volume $(\mathrm{mL}) /$ fresh weight of tissue $(\mathrm{g})$.

\subsection{High-Performance Liquid Chromatography Quadrupole Time-of-Flight Mass Spectrometry (HPLC-Q-TOF-MS) Conditions}

The HPLC and Q-TOF-MS conditions for analyzing phenolic compounds were measured through that reported earlier by Zhao, K.H. et al. [31].

An Agilent 1260 HPLC system (Agilent Technologies, Palo Alto, CA, USA), equipped with a quat pump, an automatic sampler with a 20- $\mu \mathrm{L}$ sample loop, a thermostat of column, a diode array detector (DAD), and an Agilent ChemStation (Agilent Technologies, Palo Alto, CA, USA) had been employed to analyze samples. The mobile phase was a binary gradient prepared from acetonitrile(B) and a solution of acetic acid $0.1 \%(v / v)(A)$. It used the gradient elution procedure: B phase $0-5 \mathrm{~min}$ is $10-12 \%, 5-20 \mathrm{~min}$ is $12-15 \%, 20-25 \mathrm{~min}$ is $15-19 \%$, 25-40 $\mathrm{min}$ is $19-30 \%, 40-50 \mathrm{~min}$ is $30-40 \%, 50-55 \mathrm{~min}$ is $40-35 \%, 55-56 \mathrm{~min}$ is $35-10 \%$, 56-65min is $10-10 \%$. An Agilent-ZORBAX SB-C 18 column $(250 \mathrm{~mm} \times 4.6 \mathrm{~mm}$, $5 \mu \mathrm{m}$, Agilent Technologies, Palo Alto, CA, USA) was performed for the chromatographic separation of total polyphenol extract.

Identification of mass spectrum was employed on an accurate mass spectrometer of Agilent 6530 Q-TOF-MS (Agilent Technologies, Palo Alto, CA, USA). Chromatographic separation was employed on an Agilent-ZORBAX SB-C 18 column $(250 \mathrm{~mm} \times 4.6 \mathrm{~mm}, 5 \mu \mathrm{m}$, Agilent Technologies, Palo Alto, CA, USA), and the effluent of the HPLC mobile phase was split and guided into the electrospray ionization (ESI) source. Parameter conditions were performed as following: negative mode, capillary voltage, $3500 \mathrm{~V}$; nebulizer pressure, $50 \mathrm{psi}$; nozzle voltage, $1000 \mathrm{~V}$; flow rate of drying gas, $6 \mathrm{~L} / \mathrm{min}$; temperature of sheath gas, $350{ }^{\circ} \mathrm{C}$; flow rate of sheath gas, $11 \mathrm{~L} / \mathrm{min}$; skimmer voltage, $65 \mathrm{~V}$; OCT1 RF Vpp, $750 \mathrm{~V}$; fragmentor voltage, $135 \mathrm{~V}$. The spectra data were recorded in the range of $m / z 100-1000 \mathrm{Da}$ in a centroid pattern of full-scan MS analysis mode. The MS/MS data of the selected compounds were obtained by regulating diverse collision energy $(10-30 \mathrm{eV})$.

\subsection{Statistical Analysis}

Data were presented as the mean \pm standard deviation from at least three different experiments. All data of all groups were analyzed by one-way ANOVA using SPSS (version 23.0). All contents were expressed as dry matter. Line graphs were drawn by Origin (version 2018). Principal component analysis (PCA) was conducted with SIMCA 14.1. 
The Materials and Methods should be described with sufficient details to allow others to replicate and build on the published results. Please note that the publication of your manuscript implicates that you must make all materials, data, computer code, and protocols associated with the publication available to readers. Please disclose at the submission stage any restrictions on the availability of materials or information. New methods and protocols should be described in detail while well-established methods can be briefly described and appropriately cited.

Research manuscripts reporting large datasets that are deposited in a publicly available database should specify where the data have been deposited and provide the relevant accession numbers. If the accession numbers have not yet been obtained at the time of submission, please state that they will be provided during review. They must be provided prior to publication.

Interventionary studies involving animals or humans, and other studies that require ethical approval, must list the authority that provided approval and the corresponding ethical approval code.

\section{Results and Discussion}

\subsection{Variation in Browning and Contents of Primary Metabolites during Storage Periods}

As shown in Figure 1, the browning of fresh L. brownii bulbs was not obvious under the low temperature, while it increased with the increase in storage time and temperature. In addition, the process was accelerated by light [32].

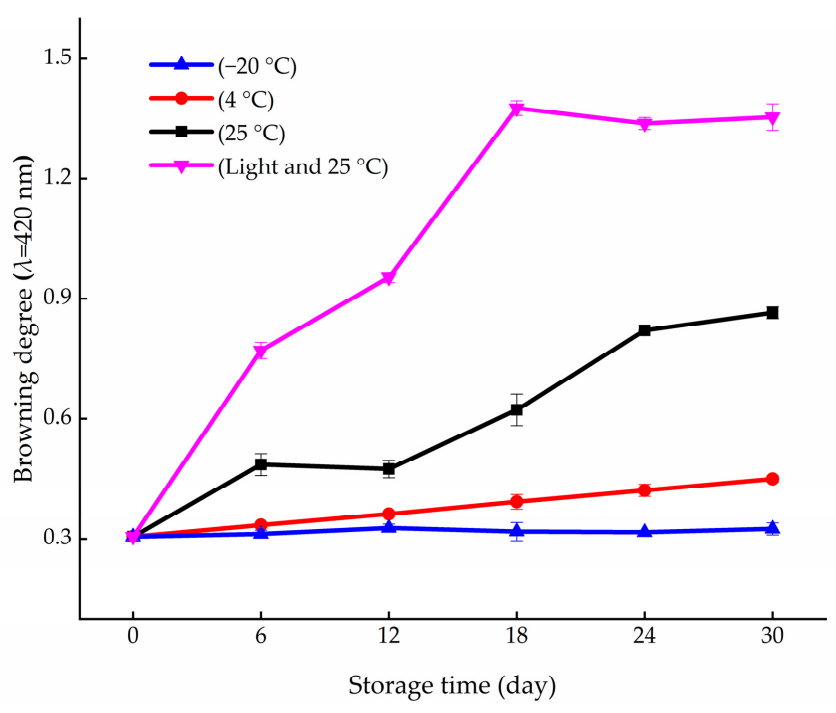

Figure 1. Variation curve of browning degree under four storage conditions.

Protein, amino acids, and sugars are the major primary metabolites in L. brownii bulbs [33]. As shown in Figure 2A, the total polysaccharide content showed a downward trend during the 30-day storage process. This indicates that carbohydrate metabolism still exists in plants under different storage conditions [34]. G1 and G2 maintained the same changing trend, which was higher than that of other groups, and they showed that refrigeration and cryopreservation weaken the life metabolism of L. brownii bulbs. When considering the effects of light, we observed that the contents of G3 were lower than those of G4, suggesting that the sugar metabolism of bulbs was more vigorous under the condition of avoiding light. 

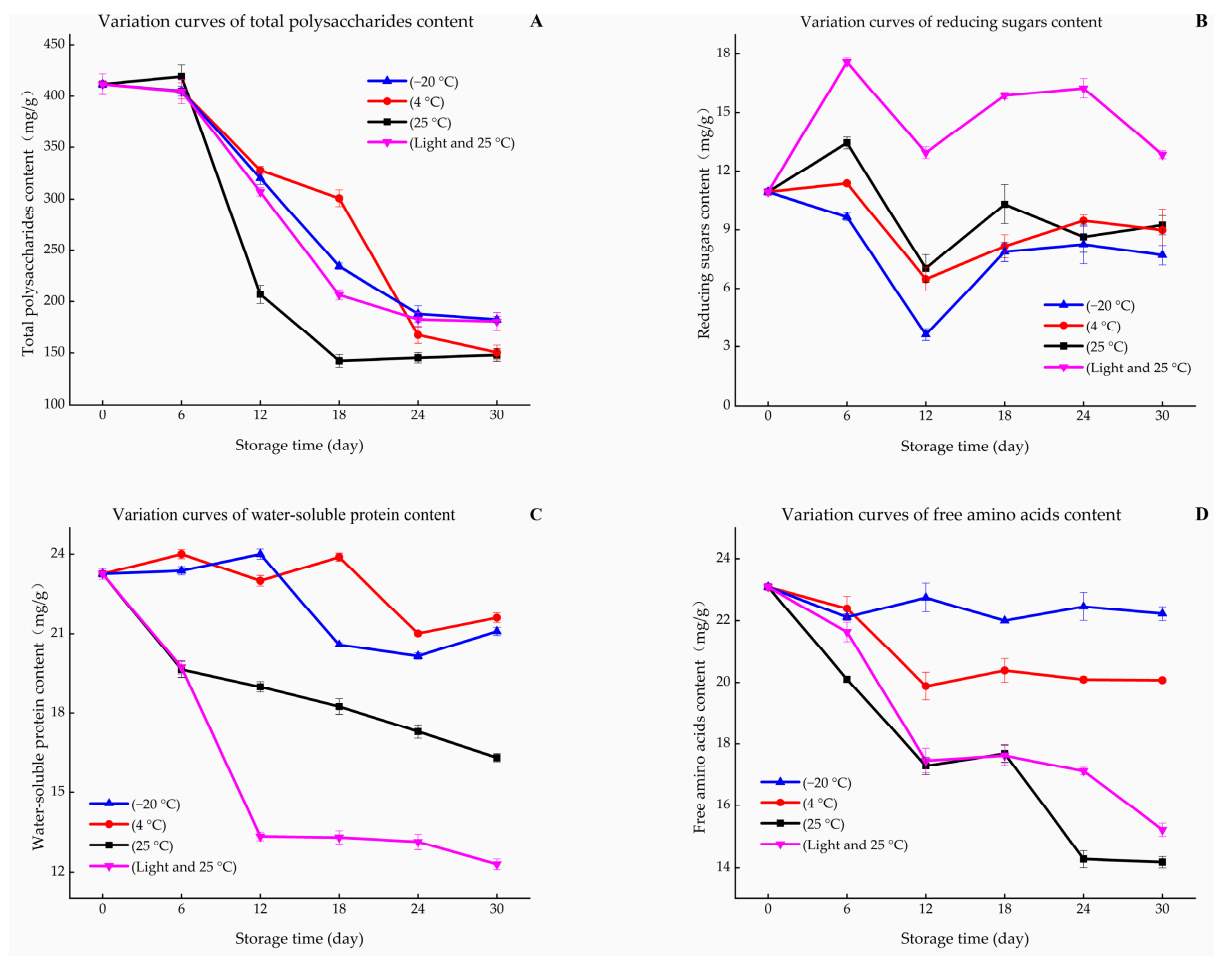

Figure 2. Variation curves of four primary metabolites under four storage conditions.

As shown in Figure 2B, the reducing sugar contents of G1, G2, and G3 increased with temperature and clearly increased under light (G4) until the 6th day. In the early stage of storage, the plant maintained relatively vigorous vitality and a faster metabolic rate, which increased the content of reducing sugars. During the period from day 6 to 12 , the content of each group decreased. This may be because reducing sugars usually provide energy for plant life activities, and plant tissues were still active before the 12th day [35]. After the 12th day, the consumption rate of reducing sugars was lower than the production rate (reducing sugars are the degradation products of polysaccharides [36]), with the vitality of the bulbs gradually decreasing (thereby causing a decline in energy demand [37]) [38]. Thus, the content of reducing sugars increased slightly.

Proteins and amino acids are involved in a variety of plant life activities [39]. As shown in Figure 2C, the water-soluble protein contents of G1 and G2 maintained the same level during the same period. This may be due to the low life activity of plant tissue and the stable protein structure at a low temperature [40]. Moreover, the two groups' contents were higher than those of G3 and G4. The reason for this may be the decrease in water-soluble protein content for the strengthened life metabolism without a source supply of $\mathrm{N}$ with the increase in storage temperature [41]. In addition, the water-soluble protein content of G4 decreased sharply and was significantly lower than that of other groups in the later stage. This may be due to the fact that the plant tissues were stimulated by light and accelerated the life metabolism rate [42].

Amino acids are the basic unit of protein [43]. The results showed that the change trend of free amino acid content in fresh L. brownii was similar to that of the protein under different storage conditions (Figure 2D). The difference is that the life activity of G1 was inhibited by the low temperature below $0{ }^{\circ} \mathrm{C}$, which caused the content change to not be significant. The bulb tissue of G2 was stored at a low temperature and maintained weak life activity, meaning that amino acids showed a slow downward trend. The contents of G3 and G4 significantly decreased because the temperature was suitable for their life activities. However, the changes in free amino acid content only showed a relationship with storage temperature and did not show the effect of light. 
According to Hodge's Maillard reaction model, the substrates in the initial stage of the model are compounds containing amino and carbonyl groups [44]. The results above show that, in the storage process, the contents of the total polysaccharides, water-solubility proteins, and free amino acids displayed a negative correlation with the change trend of the browning degree. Assuming that the Maillard reaction occurred, the content of carbonyl compounds should maintain a high negative correlation with the browning degree [45]. G1 displayed unclear browning in the storage process (Figure 1). However, the content of total polysaccharides in this group still decreased, and the amino compounds did not show a similar trend. The content variations of the two reaction substrates lacked consistency. This indicates that the changes in contents of the four nutrients were not the material basis for L. brownii browning. Thus, it was not possible to consider the notion that carbonyl and amino compounds participate in the reaction. The occurrence of the Maillard reaction could not be judged. Therefore, it can be suggested that the changes in contents of carbonyl compounds and amino compounds were caused by the physiological mechanism of adversity during the storage period [46,47].

\subsection{Variation in PPO Activity and Contents of MDA and Total Polyphenols during Storage Periods}

MDA levels indirectly reflect the degree of cell damage [48]. The increase in MDA levels suggested that the cell was damaged, which provided conditions for oxygen to enter cells, and the accumulation of phenolic compounds provided sufficient substrate for PPO [49]. Phenolic compounds are secondary metabolites of plants; they not only have pharmacological activities but are plant antitoxins [50]. As shown in Figure 3, the total polyphenol content was the lowest in G1, because the synthesis of phenolic compounds is inhibited by low temperature [51]. However, its content decreased slightly due to the influence of polyphenol oxidase, and MDA content increased as a result of freezing injury [52].

As the temperature increased up to $4{ }^{\circ} \mathrm{C}$, MDA content appeared lower than that of the other groups. Therefore, there was no obvious accumulation of phenolic compounds. Phenolic compounds would have been slightly consumed for the remaining weak activity of PPO, leading to weak browning. However, the bulbs of G3 were in an active physiological state, and the adverse factors, such as nutrient deficiency and water loss, still caused tissue damage [53]. This led to the increased MDA content and accumulation of phenolic compounds, which provided sufficient substrate for enzymatic reaction in the early stage of storage (until the 6th day). At the same time, this temperature was within the best activity temperature range of PPO, and therefore, PPO activity increased [54]. These factors caused the browning degree of G3 to be higher than that of G1 and G2. However, the metabolic capacity of tissue decreases as nutrients are consumed during storage periods [55]. This caused the contents of phenolic compounds to begin to decrease after the 6th day. PPO activity gradually became inactivate, meaning that the contents of phenolic compounds maintained a stable level in the later stage of storage (on the 24th day). Plant respiration was aggravated by light (G4), and the tissues showed severe physiological phenomenon and damage (MDA content increased rapidly), leading to the aggravated browning. G4 and G3 showed similar metabolic processes during storage, and, different to G3, PPO was passivated by long-time light. Consequently, the PPO activity of G4 decreased rapidly after the 6th day.

The results show that the total polyphenol content was closely related to storage conditions. The low temperature inhibited the increase in total polyphenol content by inhibiting plant vitality [56]. Moreover, light enhanced the stress resistance physiology of plants, which aggravated the accumulation of total polyphenols in the short storage period.

In summary, during the storage of fresh L. brownii bulbs, the stress of adversity induced tissue damage, which led to the phenolic compounds being oxidized by PPO and the occurrence of the enzymatic reaction. With the weakening of life activities and the consumption of the enzymatic reaction, the content of phenolic compounds gradually decreased. The PPO was passivated by temperature and light with the increase in storage time, which caused the intensity of the enzymatic reaction to decrease. Finally, the 
browning degree reached a high level, and the content of phenolic compounds reached the equilibrium state. Therefore, the physical and chemical parameter variation of fresh L. brownii bulbs during the storage period could be explained more reasonably from the perspective of the enzymatic browning mechanism.
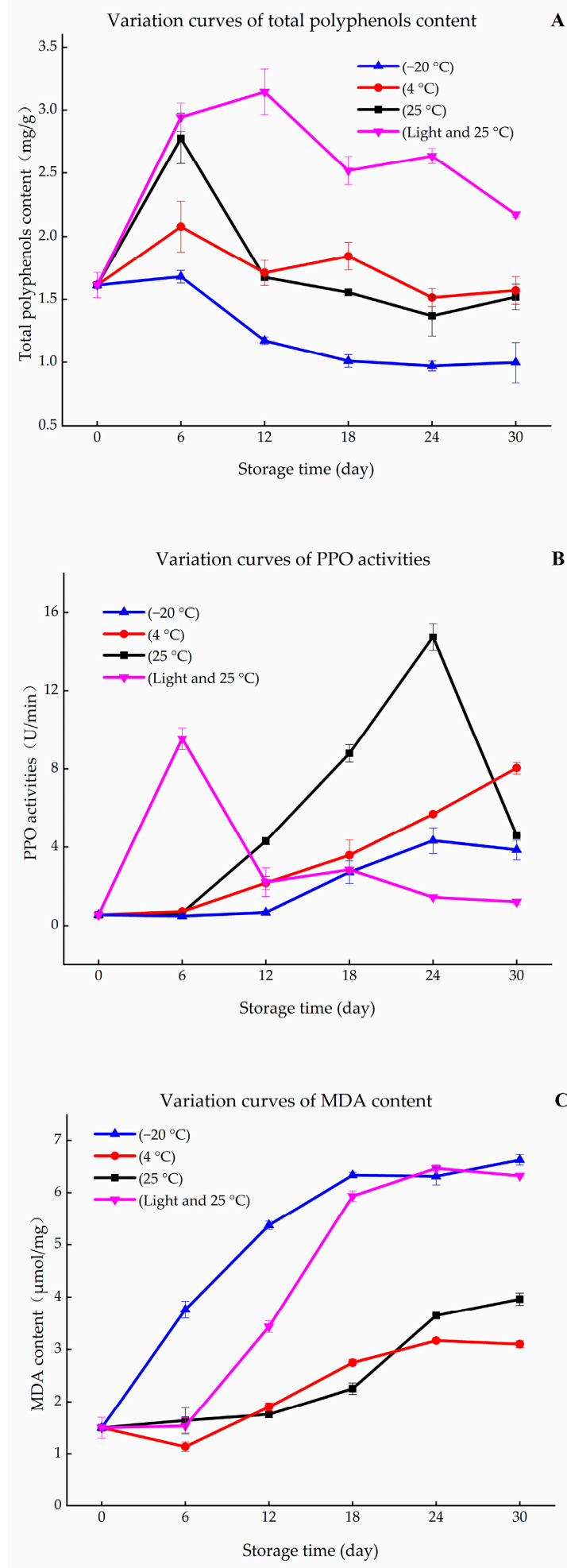

Figure 3. Variation curves of polyphenol oxidase (PPO) activity, total polyphenols, and malondialdehyde (MDA) contents under four storage conditions. 


\subsection{Identification of Phenolic Compounds Via High-Performance Liquid Chromatography Quadrupole Time-of-Flight Mass Spectrometry (HPLC-Q-TOF-MS)}

The phenolic compounds are secondary metabolites of plants, which have a wide range of biological activities, such as anti-inflammatory, antioxidant, anti-aging, and antidepressant properties [57,58]. According to the report of Luo et al. [59], the phenolic compounds in L. brownii are mainly phenylpropanoids, which have significant antioxidant activity. In our previous study [30], the 12 phenolic acids from L. brownii bulbs were identified via liquid chromatography quadrupole time-of-flight mass spectrometry (LC-Q-TOF-MS) and analysis in negative ion mode. The 12 compounds are as follows:

1-O-caffeoyl-3-O- $\beta$ - $D$-glucopyranosylglycerol (compound-1); $1-O-p$-coumaroyl-3-O- $\beta$ $D$-glucopyranosylglycerol (compound-2); 1-O-caffeoyl-3-O-p-coumaroylglycerol(compound-3); 1 -O-caffeoyl-2-O-p-coumaroylglycerol(compound-4); 1-O-feruloyl-2-O- $\beta$ - $D$ glucopyranosylglycerol(compound-5); 1-O- - -coumaroyl-2- $O-\beta$ - $D$-glucopyranosyl-3- $O$ acetylglycerol (compound-6); 1-O- $p$-coumaroyl-2-O-hydroxymethy-3-O-acetylglycerol (compound-7); 1-O-p-coumaroyl-2-O- $\beta$ - $D$-glucopyranosyl-3-O-acetylglycerol (compound-8); 1-O-feruloyl-3-O- $\beta$ - $D$-glucopyranosylglycerol(compound-9); 1,3-O-di- $p$-coumaroylglycerol (compound-10); 1-O-feruloyl-3-O-p-coumaroylglycerol(compound-11); 1,2-O-diferuloyl glycerol(compound-12).

They are mainly composed of coumarin acid, caffeic acid, and ferulic acid, which are connected by one molecule of glycerol, and the glycerol group are formed by para/ortho substitution or glucose substitution/acetylation. Hence, these compounds belong to phenolic glycerides/glycosides (phenylpropanoid compounds), and are called "regalosides" in some studies [7].

However, the contents of other phenylpropanoids, except for 1-O-caffeoyl-3-O- $p$ coumaroylglycerol, 1-O- $p$-coumaroyl-2-O- $\beta$-D-glucopyranosyl-3-O-acetylglycerol, 1-O- $p$ coumaroyl-2-O- $\beta$ - $D$-glucopyranosylglycerol, and 1-O-feruloyl-3-O- $\beta$ - $D$-glucopyranosylglycerol, are very low in the fresh $L$. brownii bulbs, which caused the cost of isolation and purification to be very high. This restricts the development and utilization of regalosides and indicates that the phenylpropanoids in L. brownii still have great research space.

\subsection{Analysis of the Relative Contents of the 12 Compounds via HPLC}

The data above show that the content of phenolic compounds is usually low in fresh L. brownii bulbs, which leads to the high cost of separation and purification. This is a barrier for the development and utilization of secondary metabolites from L. brownii bulbs. As shown in Figures 3A and 4, the content of total polyphenols has an obvious accumulation phenomenon during storage, and the main phenolic compounds in L. brownii bulbs are the 12 phenylpropanoids. Therefore, to characterize the content variation of the 12 compounds in this section, HPLC was used. The results (Tables 1 and 2) showed that the relative contents of the compounds did not change significantly when stored at $4{ }^{\circ} \mathrm{C}$ and $-20^{\circ} \mathrm{C}$. This illustrated the notion that the L. brownii bulbs' life activities were weak and that bulbs were in a state of approximate dormancy. However, the relative contents of all compounds increased significantly under a temperature of $25^{\circ} \mathrm{C}$ in light conditions for 30 days (Tables 3 and 4). This suggested that the L. brownii bulbs' life activities did not stop immediately after harvest and that the phenolic acid compounds accumulated under stress. In addition, Yin, L. B. et al. also reported that the contents of saponins, flavonoids, and polyphenols were relatively stable in the early stage (1-5 weeks) via controlled atmosphere storage, indicating that storage conditions had a significant effect on the content of secondary metabolites of L. brownii bulbs [60]. 


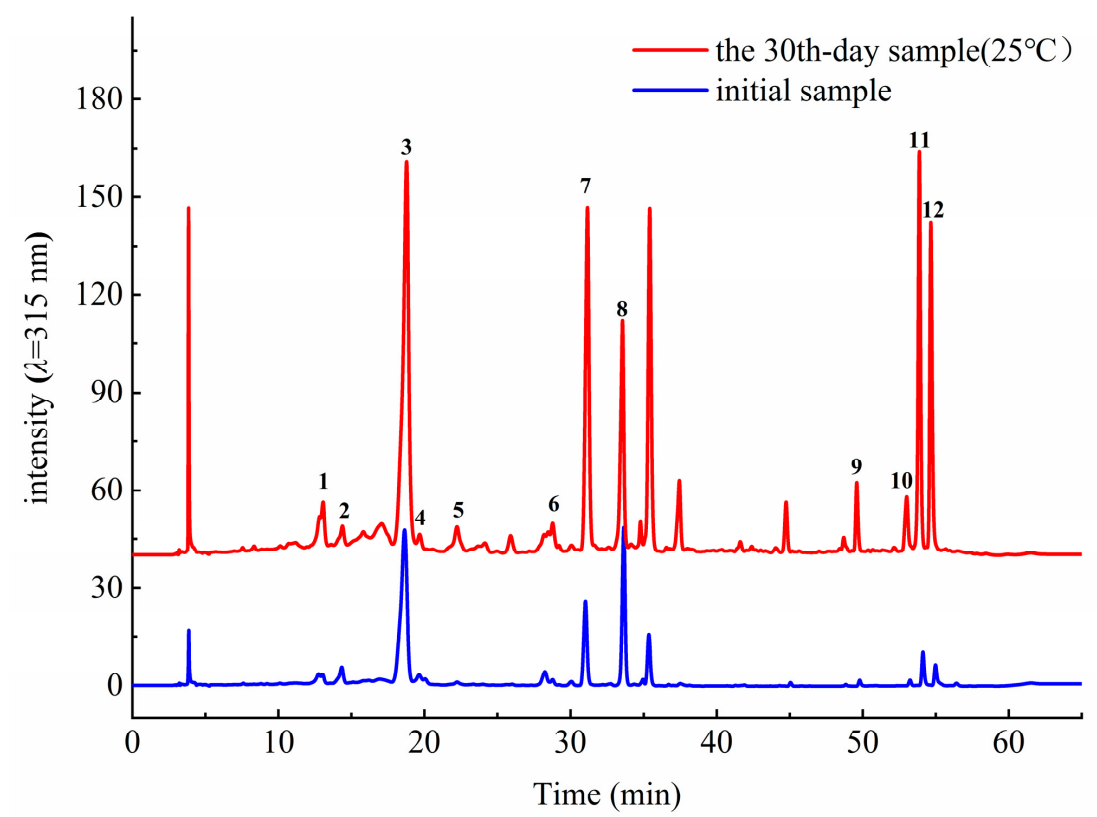

Figure 4. The high-performance liquid chromatography (HPLC) chromatogram of fresh L. brownii.

Table 1. The relative contents of the 12 compounds stored at $-20{ }^{\circ} \mathrm{C}$ for 30 days.

\begin{tabular}{|c|c|c|c|c|c|c|}
\hline Storage Time (d) & 0 & 6 & 12 & 18 & 24 & 30 \\
\hline Compound-1 & $107.06 \pm 1.12$ & $104.74 \pm 4.01$ & $134.35 \pm 3.37 \mathrm{a}$ & $143.99 \pm 3.24$ & $173.91 \pm 0.91 \mathrm{a}$ & $232.56 \pm 14.82 \mathrm{a}$ \\
\hline Compound-2 & $269.81 \pm 0.77$ & $366.66 \pm 21.92 \mathrm{a}$ & $468.30 \pm 12.85 a$ & $370.04 \pm 25.44 \mathrm{a}$ & $350.94 \pm 18.63$ & $350.21 \pm 9.19$ \\
\hline Compound-3 & $3792.36 \pm 10.64$ & $3328.57 \pm 41.58$ & $4510.88 \pm 37.21 b$ & $3879.37 \pm 29.17 a$ & $3959.79 \pm 31.76$ & $3818.84 \pm 44.48$ \\
\hline Compound-4 & $82.43 \pm 1.90$ & $50.01 \pm 2.33 a$ & $44.24 \pm 5.14$ & $48.79 \pm 2.23$ & $49.45 \pm 2.00$ & $51.25 \pm 2.33$ \\
\hline Compound-5 & $138.55 \pm 8.09$ & 0.00 & 0.00 & 0.00 & 0.00 & 0.00 \\
\hline Compound- 6 & $38.17 \pm 6.24$ & $58.65 \pm 6.74$ & $123.35 \pm 8.91 \mathrm{a}$ & $225.67 \pm 13.11 \mathrm{a}$ & $224.93 \pm 6.27$ & $153.44 \pm 0.67 \mathrm{a}$ \\
\hline Compound-7 & $65.15 \pm 1.94$ & $663.53 \pm 11.77 b$ & $110.70 \pm 0.19$ & $179.63 \pm 10.95$ & $124.48 \pm 7.34$ & $104.61 \pm 27.98$ \\
\hline Compound-8 & $1902.94 \pm 20.62$ & $1920.21 \pm 34.19$ & $2844.26 \pm 27.14 \mathrm{a}$ & $2431.70 \pm 21.32$ & $1731.18 \pm 19.50 \mathrm{a}$ & $1741.15 \pm 25.31$ \\
\hline Compound-9 & $57.18 \pm 3.13$ & 0.00 & 0.00 & 0.00 & $49.11 \pm 2.13 b$ & 0.00 \\
\hline Compound-10 & $57.13 \pm 2.75$ & 0.00 & 0.00 & 0.00 & $51.14 \pm 4.41 \mathrm{~b}$ & 0.00 \\
\hline Compound-11 & $318.89 \pm 10.10$ & $165.03 \pm 7.99 b$ & $144.05 \pm 11.36$ & $124.77 \pm 18.62$ & $246.62 \pm 9.93 \mathrm{a}$ & $59.35 \pm 4.04 b$ \\
\hline Compound-12 & $245.41 \pm 4.59$ & $108.06 \pm 9.68 b$ & $102.88 \pm 4.40$ & $108.51 \pm 3.90$ & $200.88 \pm 6.75 a$ & $68.01 \pm 4.62 b$ \\
\hline
\end{tabular}

Note: $\mathrm{a}$-compared with the former group, $p<0.05 ; \mathrm{b}$-compared with the former group, $p<0.01$.

Table 2. The relative contents of the 12 compounds stored at $4{ }^{\circ} \mathrm{C}$ for 30 days.

\begin{tabular}{|c|c|c|c|c|c|c|}
\hline Stor age Time (d) & 0 & 6 & 12 & 18 & 24 & 30 \\
\hline Compound-1 & $107.06 \pm 1.12$ & $123.90 \pm 6.10$ & $243.12 \pm 7.70 \mathrm{a}$ & $338.23 \pm 9.65 \mathrm{a}$ & $332.02 \pm 5.49$ & $462.35 \pm 2.02 \mathrm{a}$ \\
\hline Compound-2 & $269.81 \pm 0.77$ & $433.41 \pm 16.06 b$ & $464.93 \pm 23.19$ & $489.99 \pm 8.06$ & $331.14 \pm 28.23 b$ & $300.34 \pm 11.62 \mathrm{a}$ \\
\hline Compound-3 & $3792.36 \pm 10.64$ & $4467.63 \pm 79.88 \mathrm{a}$ & $8097.52 \pm 46.85 b$ & $6808.66 \pm 35.17 b$ & $4548.36 \pm 69.95 b$ & $4867.97 \pm 63.97$ \\
\hline Compound-4 & $82.43 \pm 1.90$ & $126.53 \pm 9.02 \mathrm{a}$ & $71.00 \pm 7.95 \mathrm{a}$ & $78.89 \pm 2.82$ & $60.55 \pm 4.70 \mathrm{a}$ & $53.73 \pm 3.47 \mathrm{a}$ \\
\hline Compound-5 & $138.55 \pm 8.09$ & $593.93 \pm 65.00 b$ & $350.00 \pm 44.35 b$ & $310.76 \pm 7.62$ & $182.95 \pm 3.43 b$ & $137.18 \pm 6.71 \mathrm{a}$ \\
\hline Compound-6 & $38.17 \pm 6.24$ & $50.49 \pm 2.46$ & $106.06 \pm 8.87 \mathrm{a}$ & $344.63 \pm 9.50 \mathrm{~b}$ & $126.13 \pm 6.70 b$ & $88.22 \pm 2.24 \mathrm{a}$ \\
\hline Compound-7 & $65.15 \pm 1.94$ & $1065.39 \pm 22.50 \mathrm{~b}$ & $1175.18 \pm 86.93$ & $979.67 \pm 18.98$ & $979.87 \pm 55.00$ & $676.12 \pm 52.29 b$ \\
\hline Compound-8 & $1902.94 \pm 20.62$ & $2011.81 \pm 39.71$ & $3834.91 \pm 57.62 b$ & $3175.96 \pm 78.49 \mathrm{a}$ & $3276.26 \pm 15.89$ & $1822.14 \pm 78.29 b$ \\
\hline Compound-9 & $57.18 \pm 3.13$ & $51.12 \pm 3.40$ & $40.71 \pm 3.45$ & $142.48 \pm 8.46 \mathrm{~b}$ & $77.15 \pm 7.65 \mathrm{~b}$ & $37.51 \pm 7.52 \mathrm{~b}$ \\
\hline Compound-10 & $57.13 \pm 2.75$ & $99.40 \pm 6.42$ & $148.64 \pm 8.96 \mathrm{a}$ & $137.33 \pm 9.57$ & $206.54 \pm 4.25 b$ & $219.61 \pm 13.09$ \\
\hline Compound-11 & $318.89 \pm 10.10$ & $312.24 \pm 9.63$ & $436.58 \pm 32.42 b$ & $466.44 \pm 41.59$ & $695.25 \pm 5.25 b$ & $588.63 \pm 55.47 \mathrm{a}$ \\
\hline Compound-12 & $245.41 \pm 4.59$ & $295.42 \pm 9.24$ & $295.20 \pm 11.78$ & $320.14 \pm 6.19 \mathrm{a}$ & $322.86 \pm 4.01$ & $656.28 \pm 20.75 b$ \\
\hline
\end{tabular}

Note: $a-$ compared with the former group, $p<0.05$; $b$-compared with the former group, $p<0.01$. 
Table 3. The relative contents of the 12 compounds stored at $25^{\circ} \mathrm{C}$ for 30 days.

\begin{tabular}{ccccccc}
\hline Storage Time (d) & $\mathbf{0}$ & $\mathbf{6}$ & $\mathbf{1 2}$ & $\mathbf{1 8}$ & $\mathbf{2 4}$ & $\mathbf{3 0}$ \\
\hline Compound-1 & $107.06 \pm 1.12$ & $806.38 \pm 83.77 \mathrm{~b}$ & $418.99 \pm 50.57 \mathrm{~b}$ & $390.23 \pm 44.67$ & $354.21 \pm 70.30$ & $312.80 \pm 26.72 \mathrm{a}$ \\
Compound-2 & $269.81 \pm 0.77$ & $507.73 \pm 63.91 \mathrm{~b}$ & $280.24 \pm 23.62 \mathrm{~b}$ & $221.42 \pm 17.38 \mathrm{a}$ & $208.48 \pm 10.41$ & $203.13 \pm 9.90$ \\
Compound-3 & $3792.36 \pm 10.64$ & $10447.69 \pm 90.12$ & $7129.24 \pm 54.92 \mathrm{~b}$ & $6726.39 \pm 62.35 \mathrm{a}$ & $6118.67 \pm 39.33$ & $5647.84 \pm 7.67 \mathrm{a}$ \\
Compound-4 & $82.43 \pm 1.90$ & $86.91 \pm 5.02$ & $88.66 \pm 2.03$ & $95.75 \pm 3.13$ & $115.36 \pm 9.63 \mathrm{a}$ & $92.61 \pm 3.20 \mathrm{a}$ \\
Compound-5 & $138.55 \pm 8.09$ & $501.10 \pm 25.35 \mathrm{~b}$ & $327.10 \pm 7.31 \mathrm{a}$ & $323.20 \pm 7.74$ & $332.48 \pm 8.64$ & $385.84 \pm 13.15$ \\
Compound-6 & $38.17 \pm 6.24$ & $231.16 \pm 10.56 \mathrm{~b}$ & $210.94 \pm 14.86$ & $200.58 \pm 9.78$ & $164.02 \pm 7.95 \mathrm{a}$ & $116.74 \pm 7.85 \mathrm{a}$ \\
Compound-7 & $65.15 \pm 1.94$ & $1079.15 \pm 62.58 \mathrm{~b}$ & $1166.15 \pm 48.29$ & $1170.79 \pm 22.29$ & $2527.22 \pm 14.50 \mathrm{~b}$ & $3082.76 \pm 36.60 \mathrm{~b}$ \\
Compound-8 & $1902.94 \pm 20.62$ & $3532.78 \pm 15.72 \mathrm{~b}$ & $2792.35 \pm 24.80 \mathrm{a}$ & $2293.82 \pm 63.50 \mathrm{a}$ & $1922.79 \pm 41.07 \mathrm{a}$ & $1772.28 \pm 10.83$ \\
Compound-9 & $57.18 \pm 3.13$ & $231.57 \pm 14.57 \mathrm{~b}$ & $235.06 \pm 5.83$ & $246.37 \pm 14.22$ & $211.59 \pm 8.64$ & $405.21 \pm 10.64 \mathrm{~b}$ \\
Compound-10 & $57.13 \pm 2.75$ & $188.33 \pm 9.84 \mathrm{~b}$ & $221.71 \pm 18.02 \mathrm{a}$ & $245.49 \pm 16.89$ & $294.58 \pm 7.97$ & $442.28 \pm 14.73 \mathrm{~b}$ \\
Compound-11 & $318.89 \pm 10.10$ & $1298.38 \pm 77.36 \mathrm{~b}$ & $1372.30 \pm 85.52$ & $1462.44 \pm 28.18$ & $1630.94 \pm 34.05 \mathrm{a}$ & $2534.24 \pm 23.97 \mathrm{~b}$ \\
Compound-12 & $245.41 \pm 4.59$ & $731.93 \pm 33.76 \mathrm{~b}$ & $879.45 \pm 13.08 \mathrm{a}$ & $878.87 \pm 23.88$ & $1167.70 \pm 34.13 \mathrm{a}$ & $2034.22 \pm 9.88 \mathrm{~b}$ \\
\hline
\end{tabular}

Note: a-compared with the former group, $p<0.05$; $b$-compared with the former group, $p<0.01$.

Table 4. The relative contents of the 12 compounds stored under light $\left(25^{\circ} \mathrm{C}\right)$ for 30 days.

\begin{tabular}{|c|c|c|c|c|c|c|}
\hline $\begin{array}{l}\text { Storage Time } \\
\text { (d) }\end{array}$ & 0 & 6 & 12 & 18 & 24 & 30 \\
\hline Compound-1 & $107.06 \pm 1.12$ & $1508.49 \pm 5.82 b$ & $1220.13 \pm 18.94 \mathrm{a}$ & $1240.64 \pm 3.16$ & $1352.80 \pm 7.60$ & $856.40 \pm 12.81 b$ \\
\hline Compound-2 & $269.81 \pm 0.77$ & $557.64 \pm 8.25 \mathrm{~b}$ & $398.62 \pm 4.02 \mathrm{a}$ & $365.16 \pm 3.84$ & $318.01 \pm 8.09$ & $131.95 \pm 3.58 \mathrm{~b}$ \\
\hline Compound-3 & $3792.36 \pm 10.64$ & $19552.51 \pm 66.80 b$ & $14076.69 \pm 58.97 \mathrm{a}$ & $12216.46 \pm 21.20$ & $15310.31 \pm 28.22$ & $6343.77 \pm 22.20 \mathrm{~b}$ \\
\hline Compound-4 & $82.43 \pm 1.90$ & $168.95 \pm 25.18 \mathrm{a}$ & $172.03 \pm 6.17$ & $184.10 \pm 8.10$ & $738.79 \pm 13.22 b$ & $160.86 \pm 4.11$ \\
\hline Compound-5 & $138.55 \pm 8.09$ & $761.45 \pm 17.77 \mathrm{~b}$ & $565.31 \pm 14.00 \mathrm{a}$ & $528.32 \pm 11.05$ & $476.00 \pm 9.13$ & $396.46 \pm 4.66 \mathrm{a}$ \\
\hline Compound- 6 & $38.17 \pm 6.24$ & $232.56 \pm 13.55 \mathrm{~b}$ & $319.51 \pm 9.52 \mathrm{a}$ & $427.66 \pm 5.58 \mathrm{a}$ & $345.16 \pm 7.80$ & $258.99 \pm 6.78 \mathrm{a}$ \\
\hline Compound-7 & $65.15 \pm 1.94$ & $96.74 \pm 4.62 \mathrm{a}$ & $106.42 \pm 2.64$ & $118.95 \pm 5.44$ & $146.34 \pm 5.92 \mathrm{a}$ & $97.07 \pm 2.11 \mathrm{a}$ \\
\hline Compound-8 & $1902.94 \pm 20.62$ & $5711.26 \pm 24.24 \mathrm{~b}$ & $5912.23 \pm 30.81$ & $7707.86 \pm 63.75 b$ & $5743.15 \pm 16.20 \mathrm{~b}$ & $1777.04 \pm 11.74 b$ \\
\hline Compound-9 & $57.18 \pm 3.13$ & $305.86 \pm 28.12 b$ & $347.67 \pm 14.84 \mathrm{a}$ & $337.14 \pm 8.86$ & $369.30 \pm 11.72$ & $604.24 \pm 21.24 b$ \\
\hline Compound-10 & $57.13 \pm 2.75$ & $251.67 \pm 2.22 \mathrm{~b}$ & $330.60 \pm 18.74 \mathrm{a}$ & $368.88 \pm 20.24$ & $399.97 \pm 15.89$ & $441.66 \pm 6.57 \mathrm{a}$ \\
\hline Compound-11 & $318.89 \pm 10.10$ & $1918.76 \pm 6.46 b$ & $2182.49 \pm 46.31$ & $2000.44 \pm 18.32$ & $2225.78 \pm 35.09$ & $3083.81 \pm 28.07 b$ \\
\hline Compound-12 & $245.41 \pm 4.59$ & $1173.02 \pm 28.34 b$ & $1429.78 \pm 37.72 \mathrm{a}$ & $1448.31 \pm 28.67$ & $1528.76 \pm 9.81$ & $2548.10 \pm 16.24 b$ \\
\hline
\end{tabular}

Note: $\mathrm{a}$-compared with the former group, $p<0.05 ; \mathrm{b}$-compared with the former group, $p<0.01$.

When stored at $25^{\circ} \mathrm{C}$ (as shown in Table 3), the relative contents of compounds $1,2,3$, $5,6,8$, and 11 reached the maximum value at the early stage of storage (until the 6th day), and compound 4 reached the maximum value on the 24th day. However, their contents all decreased after reaching the maximum value. This may be caused by the weakening of life metabolism. When the life metabolism became weak, phenolic compounds accumulated to a lesser extent and were consumed by oxidase, resulting in consumption being greater than generation. The contents of compounds $7,9,10$, and 12 were very low in the early stage of storage; the contents were not stable until the later stage of storage (after the 27th day); and their cumulative amounts reached the maximum. Thus, it appears that they were in a continuous accumulation state during the storage process [61].

Under a temperature of $4{ }^{\circ} \mathrm{C}$ (as shown in Table 2), the life metabolism of L. brownii bulbs were weakened, and the water loss was not obvious (stored in refrigerator). This indicates that $L$. brownii bulbs were in a dormant state; thus, the accumulation of phenolic compounds was not significant. When stored at $-20^{\circ} \mathrm{C}$ (as shown in Table 1), the $12 \mathrm{com}$ pounds almost did not show phenomenon of accumulation. This indicates that the life activities of $L$. brownii were basically stopped at $-20^{\circ} \mathrm{C}$. When the life metabolism of fresh L. brownii bulbs was inhibited by a low temperature, the contents of the 12 phenolic acids also changed slightly. Notably, with the increase in storage time, the metabolism ability of fresh L. brownii bulbs was gradually lost under a temperature of $-20^{\circ} \mathrm{C}$, resulting in the decrease in each of these compounds.

As shown in Table 4, the relative contents of compounds 1, 2, 3, and 5 reached the maximum value on the 6 th day. Unlike G3, there was a shift in the time when the relative contents of compounds 6,8 , and 11 reached their maximum values. The maximum relative content of each compound in G4 was significantly higher than that in the other three groups. The results show that the contents of phenolic acids in L. brownii bulbs increased rapidly 
when exposed to sunlight, which is similar to the results of French scholars on grapevine cutting [62]. The higher the degree of plant damage, the more obvious the accumulation of plant antitoxins. However, the stronger stress conditions aggravated the respiration of plants, making the plant tissue lose water and die quickly. After the 6th day, the L. brownii bulb tissues were seriously damaged due to the light. Eventually, they lost their vitality, which resulted in the interruption of their synthesis. Moreover, the consumption of other pathways and the degradation of the compounds still existed under strong light conditions, which finally contributed to the decrease in compound content.

In conclusion, the contents of phenolic acid compounds in fresh L. brownii bulbs were very low. In addition, the content of phenolic compounds was accumulated in bulbs under adverse conditions. In fact, L. brownii bulbs being damaged by sale delay or other factors is inevitable. L. brownii without commercial value could be used for the extraction and separation of phenolic acids to avoid the waste of resources. Furthermore, the accumulation of compounds through stress physiology is an effective way to improve the utilization rate of $L$. brownii resources and the development of phenolic acids.

3.5. Principal Component Analysis of 8 Physicochemical Parameters, the 12 Phenolic Compounds, and Storage Time

The principal component analysis of the indicators in the chart above was applied to illustrate the correlations between the parameters and browning degree. The changes in physicochemical parameters were normal physiological phenomena after harvest of fresh L brownii bulbs. When stored at $-20^{\circ} \mathrm{C}$, the parameters and the 12 phenolic acids displayed almost discrete distribution and did not show a certain correlation (as shown in Figure 5). Combined with the data above, the results showed that the life metabolism of fresh L. brownii bulbs was inhibited, and, except for total polysaccharide level, the changes in each index level were not significant. With the increase in storage temperature (Figures 6 and 7), the browning degree showed significant correlation with storage time, MDA, and PPO activity and was closely related to compounds 9, 10, 11, and 12. When exposed to light at $25{ }^{\circ} \mathrm{C}$ (Figure 8), the browning degree had a significant correlation with MDA and compounds 9, 10,11, and 12, while it had a very low correlation with PPO activity. According to the analysis of PPO activity level in Figure 3B, PPO activity was inhibited by light, but the total polyphenol content increased in the early stage of storage. Therefore, PPO activity increased briefly in the early stage of storage, and then it decreased to a low level. This trend deviated from the variation trend of the browning degree level, which may lead to the deviation of PPO activity from the browning degree.

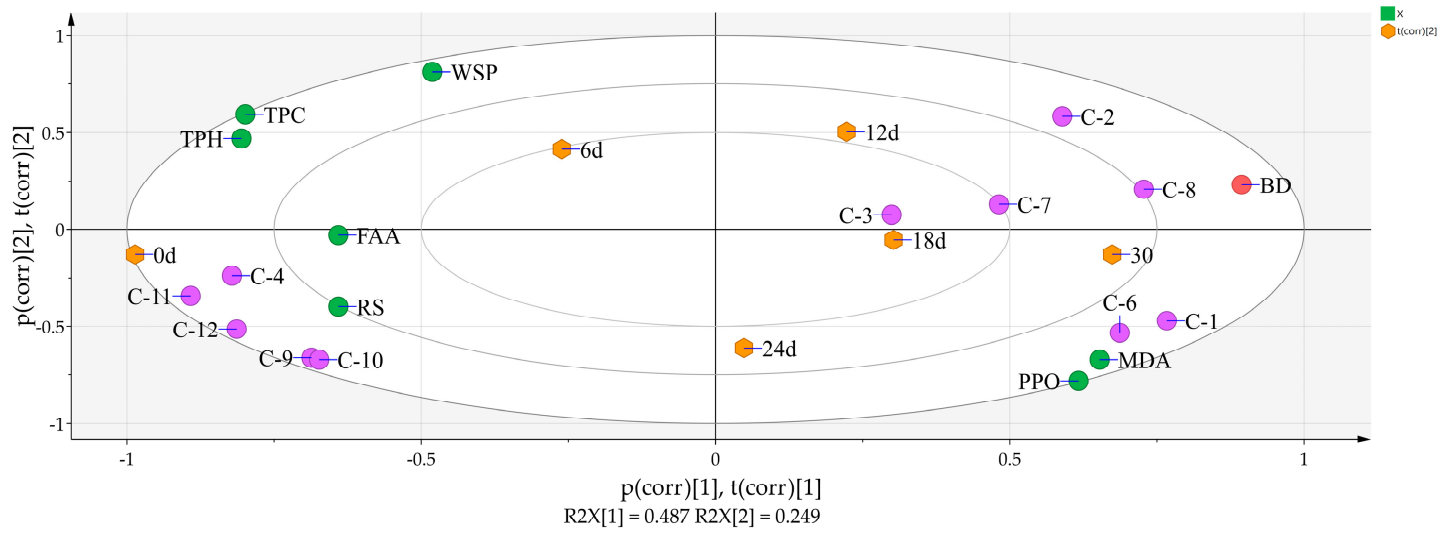

Figure 5. Multivariate statistical analysis of each index of G1. 

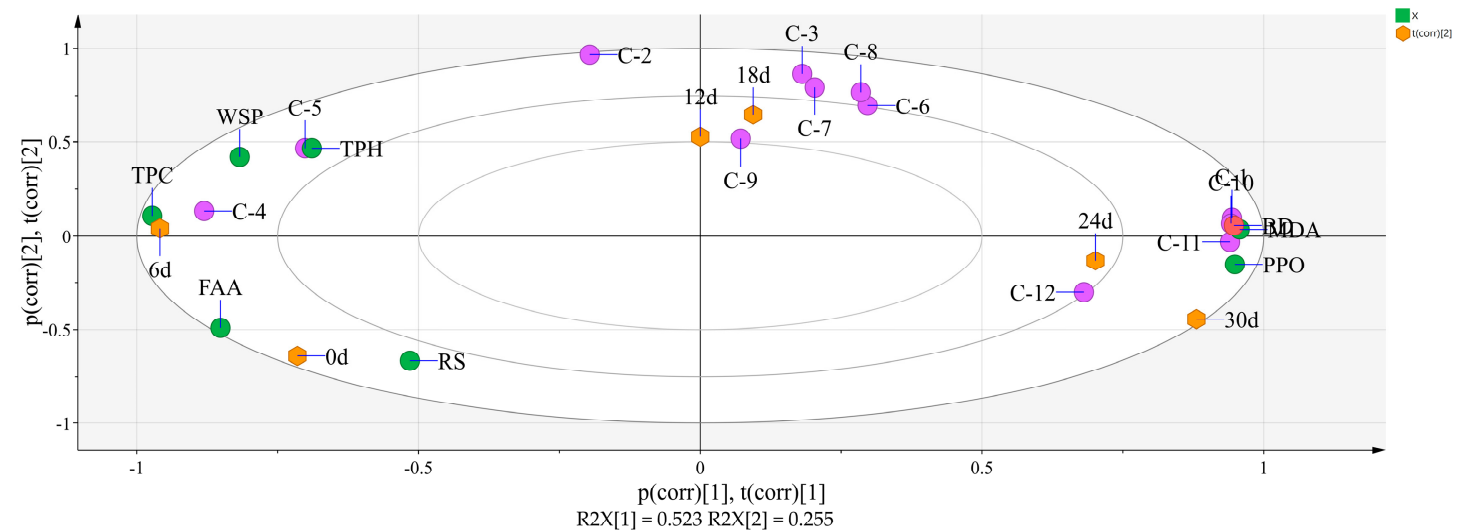

Figure 6. Multivariate statistical analysis of each index of G2.

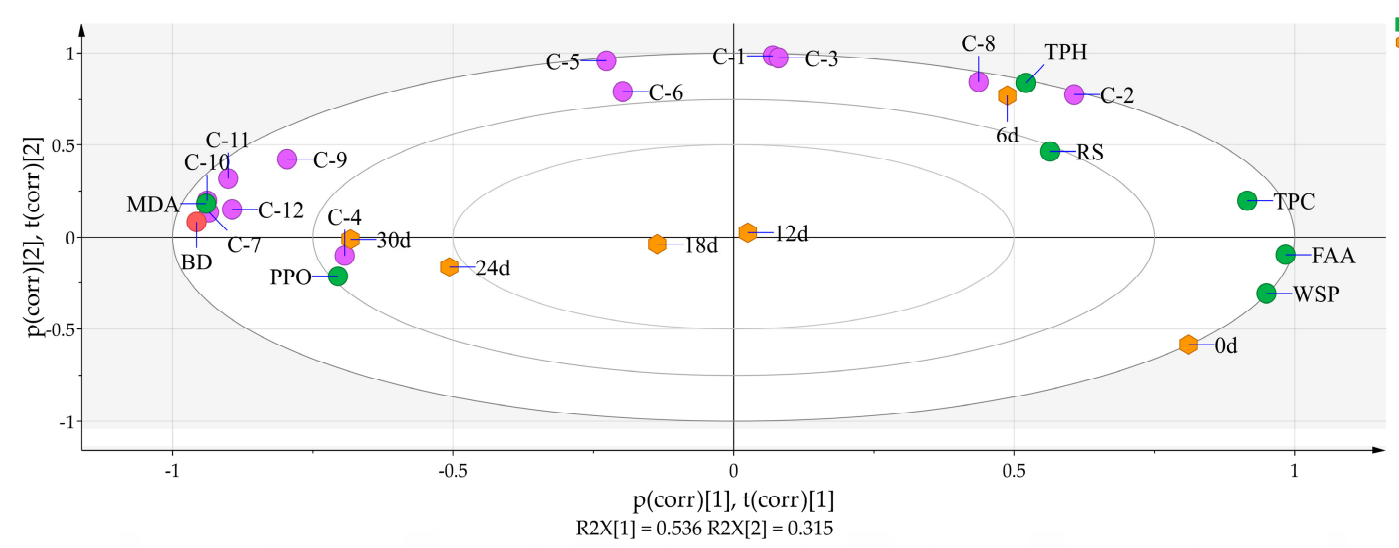

Figure 7. Multivariate statistical analysis of each index of G3.

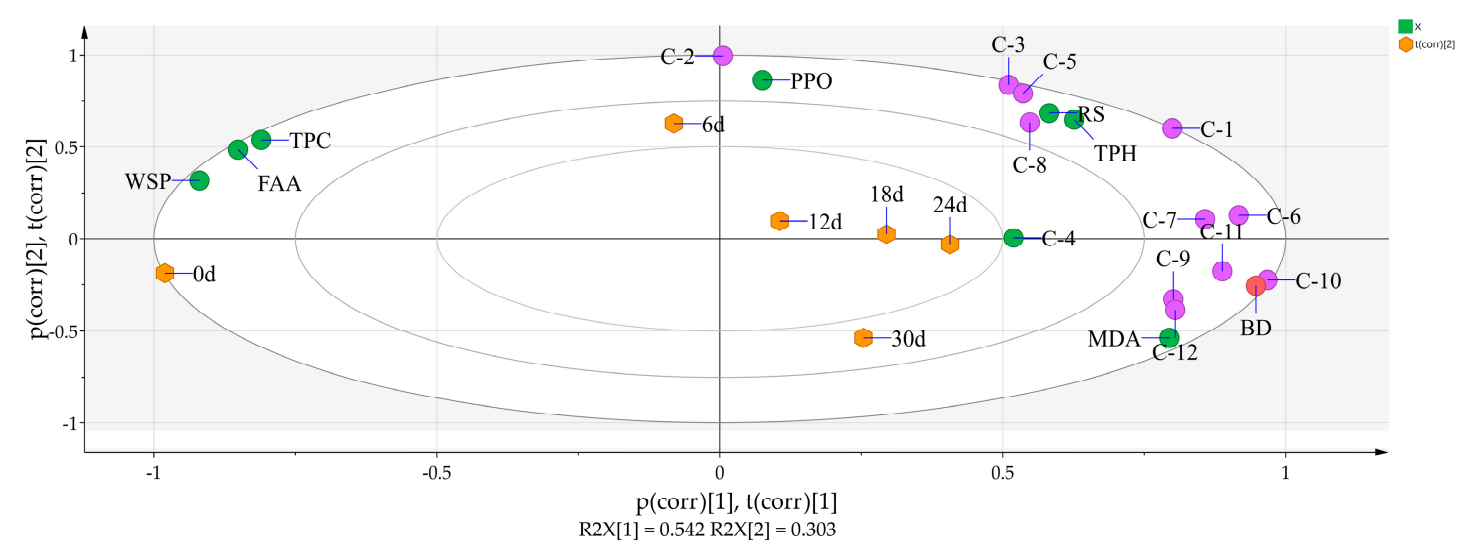

Figure 8. Multivariate statistical analysis of each index of G4. Note: Figures 5-8: C-1 to C-12 means compound-1 to compound-12; RS means reducing sugars; WSP means water-soluble proteins; BD means browning degree; TPC means total polysaccharides; TPH means total polyphenols.

While PCA analysis did not show the correlation between browning degree and total polysaccharides, free amino acids, water-soluble proteins, and reducing sugars levels, it further verified the conclusion that the browning of fresh L. brownii bulbs could not be explained from the perspective of the Maillard reaction. In addition, the correlation between total polyphenol content and browning degree was not significant. This was mainly due to the influence of life metabolism on the level of phenolic compounds. The accumulation occurred in the early stage, resulting in the difference between the change in level and browning degree during the whole storage period. 
In conclusion, the browning of fresh L. brownii bulbs was mainly related to storage time; the levels of MDA; PPO; and compounds 9, 10, 11, and 12 but not to the factors of nonenzymatic browning. Although the correlation between total polyphenols and browning in L. brownii was not shown statistically, it was found that the phenolic compounds 9, 10, 11, and 12 were closely related to browning. It is worth noting that the contents of compounds $1,2,3,5,6,7$, and 8 changed significantly. Due to the fact that their contents increased first and then decreased during the storage period, correlations with browning could not be found from the statistical point of view, but this could be due to the fact that they are not related to browning. Therefore, the influence mechanism of phenolic substrates on browning still need to be further studied; for instance, the reaction characteristics of PPO with substrate and a control variable, and combined with biological technology could be examined. Further research on the dynamic changes in phenolic compounds in L. brownii will contribute to explaining not only the browning mechanism of fresh L. brownii bulbs but also the stress physiological mechanism.

\section{Conclusions}

In this study, the results showed that the contents of nutrients in fresh L. brownii bulbs decreased during the storage period, which was accelerated by light and a high temperature, and the appearance became worse. However, while the reducing sugars and amino acids are the main participants in the Maillard reaction, their content changes did not match the changes observed for the browning degree.

The low temperature below freezing point can keep L. brownii bulbs fresh to the maximum extent. However, they display obvious freezing injury after thawing, and, thus, they should be stored at a low temperature (above $0{ }^{\circ} \mathrm{C}$ ) and in the dark. The changes observed in PPO activity, total polyphenols, and MDA content could be described from the perspective of the enzymatic browning mechanism.

Concurrently, through the PCA of the variation of 8 physicochemical parameters and correlation with the 12 phenolic acids, L. brownii browning was observed to be mainly caused by enzymatic reaction. In addition, the contents of nutrients and the appearance quality decreased when stored in light conditions at room temperature. This led to the effective accumulation of phenolic acid compounds (phenylpropanoids), which provide a novel visual angle to develop and utilize phenolic acids in L. brownii and reuse waste resources.

Author Contributions: K.Z. and H.X. conceived and designed the experiments; K.Z. and Z.X. performed the experiments and designed the figures; K.Z. analyzed and helped in data interpretation; K.Z. wrote the manuscript; H.X. and J.Z. edited and supported suggestions for the manuscript. All authors have read and agreed to the published version of the manuscript.

Funding: This research was funded by the China Agriculture Research System (No. CARS-21), the special fund for local science and technology development guided by the central government to Hunan province (No. 2019XF5074), the special fund for local science and technology development guided by the central government (No. 2019XF5061), the Hunan Province Agriculture Research System (No. [2019]0047).

Data Availability Statement: The data presented in this study are available on request from the corresponding author.

Conflicts of Interest: All authors have no conflicts of interest.

\section{References}

1. Wang, T.; Huang, H.; Zhang, Y.; Li, X.; Li, H.; Jiang, Q.; Gao, W. Role of effective composition on antioxidant, anti-inflammatory, sedative-hypnotic capacities of 6 common edible Lilium varieties. J. Food Sci. 2015, 80, H857-H868. [CrossRef] [PubMed]

2. Chinese Pharmacopoeia Commission. Pharmacopoeia of the People Republic of China; Chinese Medical Science and Technology Press: Beijing, China, 2020; pp. 132-133.

3. Hou, Y.; Jiang, J.G. Origin and concept of medicine food homology and its application in modern functional foods. Food Funct. 2013, 4, 1727-1741. [CrossRef] [PubMed] 
4. Ma, T.; Wang, Z.; Zhang, Y.M.; Luo, J.G.; Kong, L.Y. Bioassay-guided isolation of anti-inflammatory components from the bulbs of Lilium brownii var. viridulum and identifying the underlying mechanism through acting on the NF-kappaB/MAPKs Pathway. Molecules 2017, 22, 506. [CrossRef] [PubMed]

5. Hong, X.X.; Luo, J.G.; Guo, C.; Kong, L.Y. New steroidal saponins from the bulbs of Lilium brownii var. viridulum. Carbohyd. Res. 2012, 361, 19-26. [CrossRef]

6. Pan, G.; Xie, Z.; Huang, S.; Tai, Y.; Cai, Q.; Jiang, W.; Sun, J.; Yuan, Y. Immune-enhancing effects of polysaccharides extracted from Lilium lancifolium Thunb. Int. Immunopharmacol. 2017, 52, 119-126. [CrossRef]

7. Munafo, J.P., Jr.; Gianfagna, T.J. Quantitative analysis of phenylpropanoid glycerol glucosides in different organs of Easter Lily (Lilium longiflorum Thunb.). J. Agric. Food Chem. 2015, 63, 4836-4842. [CrossRef]

8. Yuan, Z.Y.; Li, Z.Y.; Zhao, H.Q.; Gao, C.; Xiao, M.W.; Jiang, X.M.; Zhu, J.P.; Huang, H.Y.; Xu, G.M.; Xie, M.Z. Effects of different drying methods on the chemical constituents of Lilium lancifolium Thunb. based on UHPLC-MS analysis and antidepressant activity of the main chemical component regaloside A. J. Sep. Sci. 2020. [CrossRef]

9. Azadi, P.; Khosh-Khui, M. Micropropagation of Lilium ledebourii (Baker) Boiss as affected by plant growth regulator, sucrose concentration, harvesting season and cold treatments. Electron. J. Biotechnol. 2007, 10, 582-591. [CrossRef]

10. Aydin, B.; Gulcin, I.; Alwasel, S.H. Purification and characterization of polyphenol oxidase from Hemsin Apple (Malus communis L.). Int. J. Food Prop. 2015, 18, 2735-2745. [CrossRef]

11. Segovia-Bravo, K.A.; Jarén-Galán, M.; García-García, P.; Garrido-Fernández, A. Browning reactions in olives: Mechanism and polyphenols involved. Food Chem. 2009, 114, 1380-1385. [CrossRef]

12. Krzyzanowski, A.; Saleeb, M.; Elofsson, M. Synthesis of Indole-, Benzo[b]thiophene-, and Benzo[b] selenophene-Based Analogues of the Resveratrol Dimers Viniferifuran and (+/-)-Dehydroampelopsin B. Org. Lett. 2018, 20, 6650-6654. [CrossRef] [PubMed]

13. Guerrero, R.F.; Biais, B.; Richard, T.; Puertas, B.; Waffo-Teguo, P.; Merillon, J.M.; Cantos-Villar, E. Grapevine cane's waste is a source of bioactive stilbenes. Ind. Crop. Prod. 2016, 94, 884-892. [CrossRef]

14. Tsikas, D. Assessment of lipid peroxidation by measuring malondialdehyde (MDA) and relatives in biological samples: Analytical and biological challenges. Anal. Biochem. 2017, 524, 13-30. [CrossRef]

15. Saura, D.; Vegara, S.; Marti, N.; Valero, M.; Laencina, J. Non-enzymatic browning due to storage is reduced by using clarified lemon juice as acidifier in industrial-scale production of canned peach halves. J. Food Sci. Technol. 2017, 54, 1873-1881. [CrossRef]

16. Nooshkam, M.; Varidi, M.; Bashash, M. The Maillard reaction products as food-born antioxidant and antibrowning agents in model and real food systems. Food Chem. 2019, 275, 644-660. [CrossRef]

17. Cha, J.; Debnath, T.; Lee, K.G. Analysis of alpha-dicarbonyl compounds and volatiles formed in Maillard reaction model systems. Sci. Rep. 2019, 9, 5325. [CrossRef]

18. Farcuh, M.; Copes, B.; Le-Navenec, G.; Marroquin, J.; Cantu, D.; Bradford, K.J.; Guinard, J.X.; Van Deynze, A. Sensory, physicochemical and volatile compound analysis of short and long shelf-life melon (Cucumis melo L.) genotypes at harvest and after postharvest storage. Food Chem. 2020, 8, 100107. [CrossRef] [PubMed]

19. Zhu, S.; Feng, L.; Zhang, C.; Bao, Y.; He, Y. Identifying freshness of Spinach leaves stored at different temperatures using hyperspectral imaging. Foods 2019, 8, 356. [CrossRef]

20. Kan, J.; Xie, W.J.; Wan, B.; Huo, T.B.; Lin, X.P.; Liu, J.; Jin, C.H. Heat-induced tolerance to browning of fresh-cut lily bulbs (Lilium lancifolium Thunb.) under cold storage. J. Food Biochem. 2019, 43, e12816. [CrossRef] [PubMed]

21. Hoch, W.A.; Singsaas, E.L.; McCown, B.H. Resorption protection. Anthocyanins facilitate nutrient recovery in autumn by shielding leaves from potentially damaging light levels. Plant Physiol. 2003, 133, 1296-1305. [CrossRef] [PubMed]

22. Logan, B.A.; Stafstrom, W.C.; Walsh, M.J.L.; Reblin, J.S.; Gould, K.S. Examining the photoprotection hypothesis for adaxial foliar anthocyanin accumulation by revisiting comparisons of green- and red-leafed varieties of coleus (Solenostemon scutellarioides). Photosynth. Res. 2015, 124, 267-274. [CrossRef] [PubMed]

23. Cho, J.S.; Moon, K.D. Comparison of image analysis methods to evaluate the degree of browning of fresh-cut lettuce. Food Sci. Biotechnol. 2014, 23, 1043-1048. [CrossRef]

24. Zhang, J.; Gao, Y.; Zhou, X.; Hu, L.; Xie, T. Chemical characterisation of polysaccharides from Lilium davidii. Nat. Prod. Res. 2010, 24, 357-369. [CrossRef] [PubMed]

25. Chen, J.; Wu, S.S.; Liang, R.H.; Liu, W.; Liu, C.M.; Shuai, X.X.; Wang, Z.J. The effect of high speed shearing on disaggregation and degradation of pectin from creeping fig seeds. Food Chem. 2014, 165, 1-8. [CrossRef] [PubMed]

26. Chen, X.; Song, W.; Zhao, J.; Zhang, Z.; Zhang, Y. Some physical properties of protein moiety of Alkali-extracted tea polysaccharide conjugates were shielded by its polysaccharide. Molecules 2017, 22, 914. [CrossRef] [PubMed]

27. National Institute of Measurement and Testing Technology. Tea-Determination of Free Amino Acids Content; AQSIQ: Beijing, China, 2014; Volume GB/T 8314-2013.

28. Jin, L.; Zhang, Y.; Yan, L.; Guo, Y.; Niu, L. Phenolic compounds and antioxidant activity of bulb extracts of six Lilium species native to China. Molecules 2012, 17, 9361-9378. [CrossRef] [PubMed]

29. Siddiq, M.; Dolan, K.D. Characterization of polyphenol oxidase from blueberry (Vaccinium corymbosum L.). Food Chem. 2017, 218, 216-220. [CrossRef]

30. Janero, D.R. Malondialdehyde and thiobarbituric acid-reactivity as diagnostic indices of lipid peroxidation and peroxidative tissue injury. Free Radic. Biol. Med. 1990, 9, 515-540. [CrossRef] 
31. Zhao, K.H.; Zhou, F.; Yan, S.E.; Liu, D.B.; Xie, H.Q. The analysis of compounds from Longya Lilium via HPLC-Q-TOF-MS and HS-SPME-GC-MS. Nat. Prod. Res. Dev. 2020, 32, 1331-1342. [CrossRef]

32. Narbona, E.; Jaca, J.; del Valle, J.C.; Valladares, F.; Buide, M.L. Whole-plant reddening in Silene germana is due to anthocyanin accumulation in response to visible light. Plant Biol. 2018, 20, 968-977. [CrossRef] [PubMed]

33. Khan, N.; Ali, S.; Zandi, P.; Mehmood, A.; Ullah, S.; Ikram, M.; Ismail, M.A.S.; Babar, A. Role of Sugars, Amino acids and organic acids in improving plant abiotic stress tolerance. Pak. J. Bot. 2020, 52, 355-363. [CrossRef]

34. Sun, Y.J.; Shi, Z.D.; Jiang, Y.P.; Zhang, X.H.; Li, X.A.; Li, F.J. Effects of preharvest regulation of ethylene on carbohydrate metabolism of apple (Malus domestica Borkh cv. Starkrimson) fruit at harvest and during storage. Sci. Hortic. 2021, 276, 109748. [CrossRef]

35. Saddhe, A.A.; Manuka, R.; Penna, S. Plant sugars: Homeostasis and transport under abiotic stress in plants. Physiol. Plant. 2020. [CrossRef] [PubMed]

36. Das, B.; Sahoo, R.N.; Pargal, S.; Krishna, G.; Verma, R.; Chinnusamy, V.; Sehgal, V.K.; Gupta, V.K.; Dash, S.K.; Swain, P. Quantitative monitoring of sucrose, reducing sugar and total sugar dynamics for phenotyping of water-deficit stress tolerance in rice through spectroscopy and chemometrics. Spectrochim. Acta A Mol. Biomol. Spectrosc. 2018, 192, 41-51. [CrossRef]

37. Furtauer, L.; Weiszmann, J.; Weckwerth, W.; Nagele, T. Dynamics of plant metabolism during cold acclimation. Int. J. Mol. Sci. 2019, 20, 5411. [CrossRef] [PubMed]

38. Huang, Y.H.; Picha, D.H.; Kilili, A.W.; Johnson, C.E. Changes in invertase activities and reducing sugar content in sweetpotato stored at different temperatures. J. Agric. Food Chem. 1999, 47, 4927-4931. [CrossRef]

39. Hierl, G.; Vothknecht, U.; Gietl, C. Programmed cell death in Ricinus and Arabidopsis: The function of KDEL cysteine peptidases in development. Physiol. Plant. 2012, 145, 103-113. [CrossRef]

40. Chodankar, S.; Aswal, V.K.; Kohlbrecher, J.; Vavrin, R.; Wagh, A.G. Small-angle neutron scattering study of structure and kinetics of temperature-induced protein gelation. Phys. Rev. E 2009, 79, 021912. [CrossRef]

41. Goldford, J.E.; Hartman, H.; Marsland, R.; Segre, D. Environmental boundary conditions for the origin of life converge to an organo-sulfur metabolism. Nat. Ecol. Evol. 2019, 3, 1715-1724. [CrossRef] [PubMed]

42. Park, J.E.; Kim, J.; Purevdorj, E.; Son, Y.J.; Nho, C.W.; Yoo, G. Effects of long light exposure and drought stress on plant growth and glucosinolate production in pak choi (Brassica rapa subsp. chinensis). Food Chem. 2021, 340, 128167. [CrossRef]

43. Di Gioia, M.L.; Leggio, A.; Malagrino, F.; Romio, E.; Siciliano, C.; Liguori, A. N-methylated $\alpha$-amino acids and peptides: Synthesis and biological activity. Mini. Rev. Med. Chem. 2016, 16, 683-690. [CrossRef]

44. Yu, H.; Seow, Y.X.; Ong, P.K.C.; Zhou, W. Kinetic study of high-intensity ultrasound-assisted Maillard reaction in a model system of d-glucose and glycine. Food Chem. 2018, 269, 628-637. [CrossRef]

45. Quan, W.; Wu, Z.L.; Jiao, Y.; Liu, G.P.; Wang, Z.J.; He, Z.Y.; Tao, G.J.; Qin, F.; Zeng, M.M.; Chen, J. Exploring the relationship between potato components and Maillard reaction derivative harmful products using multivariate statistical analysis. Food Chem. 2021, 339, 127853. [CrossRef] [PubMed]

46. Aubert, C.; Chalot, G.; Lurol, S.; Ronjon, A.; Cottet, V. Relationship between fruit density and quality parameters, levels of sugars, organic acids, bioactive compounds and volatiles of two nectarine cultivars, at harvest and after ripening. Food Chem. 2019, 297, 124954. [CrossRef]

47. Shi, L.Y.; Cao, S.F.; Shao, J.R.; Chen, W.; Yang, Z.F.; Zheng, Y.H. Chinese bayberry fruit treated with blue light after harvest exhibit enhanced sugar production and expression of cryptochrome genes. Postharvest Biol. Technol. 2016, 111, 197-204. [CrossRef]

48. Yonny, M.E.; Torressi, A.R.; Nazareno, M.A.; Cerutti, S. Development of a novel, sensitive, selective, and fast methodology to determine malondialdehyde in leaves of melon plants by ultra-high-performance liquid chromatography-tandem mass spectrometry. J. Anal. Methods Chem. 2017, 2017, 4327954. [CrossRef]

49. Yan, S.L.; Yang, T.B.; Luo, Y.G. The mechanism of ethanol treatment on inhibiting lettuce enzymatic browning and microbial growth. LWT-Food Sci. Technol. 2015, 63, 383-390. [CrossRef]

50. Brillante, L.; De Rosso, M.; Dalla Vedova, A.; Maoz, I.; Flamini, R.; Tomasi, D. Insights on the stilbenes in Raboso Piave grape (Vitis vinifera L.) as a consequence of postharvest vs on-vine dehydration. J. Sci. Food Agric. 2018, 98, 1961-1967. [CrossRef] [PubMed]

51. Alfeo, V.; Bravi, E.; Ceccaroni, D.; Sileoni, V.; Perretti, G.; Marconi, O. Effect of baking time and temperature on nutrients and phenolic compounds content of fresh sprouts breadlike product. Foods 2020, 9, 1447. [CrossRef] [PubMed]

52. Suleman, P.; Redha, A.; Afzal, M.; Al-Hasan, R. Temperature-induced changes of malondialdehyde, heat-shock proteins in relation to chlorophyll fluorescence and photosynthesis in Conocarpus lancifolius (Engl.). Acta Physiol. Plant. 2013, 35, 1223-1231. [CrossRef]

53. Zhang, Z.Y.; Jin, H.B.; Suo, J.W.; Yu, W.Y.; Zhou, M.Y.; Dai, W.S.; Song, L.L.; Hu, Y.Y.; Wu, J.S. Effect of temperature and humidity on oil quality of harvested Torreya grandis cv. Merrillii nuts during the after-ripening stage. Front. Plant. Sci. 2020, 11, 573681. [CrossRef]

54. Peng, X.Y.; Du, C.; Yu, H.Y.; Zhao, X.Y.; Zhang, X.Y.; Wang, X.Y. Purification and characterization of polyphenol oxidase (PPO) from water yam (Dioscorea alata). CyTA J. Food 2019, 17, 676-684. [CrossRef]

55. Zhang, J.H.; Li, C.Y.; Wei, M.L.; Ge, Y.H.; Tang, Q.; Xue, W.J.; Zhang, S.Y.; Wang, W.H.; Lv, J.Y. Effects of trisodium phosphate treatment after harvest on storage quality and sucrose metabolism in jujube fruit. J. Sci. Food Agric. 2019, 99, 5526-5532. [CrossRef]

56. Balasooriya, H.N.; Dassanayake, K.B.; Seneweera, S.; Ajlouni, S. Impact of elevated carbon dioxide and temperature on strawberry polyphenols. J. Sci. Food Agric. 2019, 99, 4659-4669. [CrossRef]

57. Simsek, M.; Quezada-Calvillo, R.; Nichols, B.L.; Hamaker, B.R. Phenolic compounds increase the transcription of mouse intestinal maltase-glucoamylase and sucrase-isomaltase. Food Funct. 2017, 8, 1915-1924. [CrossRef] [PubMed] 
58. Mo, E.J.; Ahn, J.H.; Jo, Y.H.; Kim, S.B.; Hwang, B.Y.; Lee, M.K. Inositol derivatives and phenolic compounds from the roots of Taraxacum coreanum. Molecules 2017, 22, 1349. [CrossRef]

59. Luo, J.; Li, L.; Kong, L. Preparative separation of phenylpropenoid glycerides from the bulbs of Lilium lancifolium by high-speed counter-current chromatography and evaluation of their antioxidant activities. Food Chem. 2012, 131, 1056-1062. [CrossRef]

60. Yin, L.B.; Liao, C.; Yang, A.L.; Liu, D.; He, P.; Liu, Y.L.; Li, L.L. Effect of the controlled atmosphere storage on the quality of Lilium brownii bulbs. Int. J. Agric. Biol. 2020, 24, 1607-1613. [CrossRef]

61. Li, X.D.; Wu, B.H.; Wang, L.J.; Zheng, X.B.; Yan, S.T.; Li, S.H. Changes in trans-resveratrol and other phenolic compounds in grape skin and seeds under low temperature storage after post-harvest UV-irradiation. J. Hortic. Sci. Biotechnol. 2009, 84, 113-118. [CrossRef]

62. Billet, K.; Houille, B.; Besseau, S.; Melin, C.; Oudin, A.; Papon, N.; Courdavault, V.; Clastre, M.; Giglioli-Guivarc'h, N.; Lanoue, A. Mechanical stress rapidly induces $E$-resveratrol and E-piceatannol biosynthesis in grape canes stored as a freshly-pruned byproduct. Food Chem. 2018, 240, 1022-1027. [CrossRef] 